\author{
Volume 1, Nomor 1, Juni 2020, Hal 15-28 \\ INFOTECH: Jurnal Informatika \& Teknologi \\ p ISSN 2722-9378 | e ISSN 2722-9386
}

\title{
IMPLEMENTASI APLIKASI ASISTENSI GURU DI KELAS DENGAN TEKNIK GEOFENCING BERBASIS ANDROID
}

\author{
Iskandar ${ }^{1}$, Umar Tsani Abdurrahman² \\ $1^{*, 2}$ Program Studi Teknik Informatika, Sekolah Tinggi Teknologi Muhammadiyah Cileungsi. \\ 1*, 2 Jl. Anggrek No.25, Perum. PTSC, Cileungsi, Bogor, Jawa Barat, Indonesia 16820
}

Informasi Artikel
Article History:
Submission: $20-05-2020$
Revised: $20-06-2020$
Accepted: $25-06-2020$
Published: $30-06-2020$
Kata Kunci:
Asistensi Guru, Mobile,
Geofencing, GPS, Wifi
Keywords:
Geofencing, GPS, Mobile,
Teacher assistance, Wifi.
* Korespondensi:
Iskandar
iskandar@sttmcileungsi.ac.id

\begin{abstract}
Abstrak
Sebuah alat bantu belajar untuk guru dalam membantu proses pembelajaran di kelas jaman teknologi mobile sekarang ini merupakan suatu solusi untuk memudahkan rutinitas kegiatan seorang guru di kelas, untuk kasus di sekolah xyz yang penulis amati adalah mengalami permasalahan dalam proses kehadiran siswa di kelas misalnya siswa menitipkan absen dikarenakan proses kehadiran masih manual menggunakan form catatan sehingga bisa dimanipulasi, selain adanya pelanggaran juga adanya pemborosan kertas dan memerlukan space banyak untuk penyimpanan. Salah satu tindakan untuk menyelesaikan masalah ini adalah dengan dibangunnya aplikasi Asistensi Guru untuk mengelola kegiatan guru berbasis android dengan teknik geofencing, artinya sistem akan mendeteksi jika siswa tidak di ruangan kelas maka tidak bisa untuk melakukan proses kehadiran dalam pelajaran. Selanjutnya dibangun Web Services untuk melakukan rekapitulasi data kehadiran Siswa tersebut. Dengan pemanfaatan koneksi jaringan private atau WiFi, GPS dan Aplikasi Map siswa dapat melakukan kehadiran pada pelajaran yang ditempuh. Setelah dilakukan testing aplikasi asistensi guru tersebut dapat mengelola kehadiran siswa, guru dapat membuat jadwal, dan memonitor kondisi kehadiran per mata pelajaran yang diambil siswa, selanjutnya sistem dapat melakukan rekapitulasi kehadiran siswa berdasarkan pelajaran yang diambil. Dengan adanya aplikasi siswa ini dapat melakukan masuk belajar tanpa menulis di kertas kehadiran tetapi menggunakan smartphone masing-masing dan untuk rekapitulasi kehadiran siswa menggunakan aplikasi website untuk menampilkan kehadiran sesuai pelajaran yang diambil. Berdasarkan hasil pengujian aplikasi ini berjalan baik pada pada aplikasi android versi 7 keatas, dengan adanya aplikasi ini diharapkan bisa membantu guru dalam mengelola pembelajaran di kelas.
IMPLEMENTATION OF TEACHER ASSISTANCE APPLICATIONS IN CLASS WITH ANDROID-BASED GEOFENCING TECHNIQUES

\begin{tabular}{l} 
Abstract \\
\hline A learning aid for teachers in assisting the learning process in today's \\
mobile technology classroom is a solution to facilitate the routine \\
activities of a teacher in the classroom, for the case at xyz school that \\
the authors observe is experiencing problems in the process of student \\
attendance in class for example students leaving absences because the \\
attendance process is still manual using the form notes so that it can be \\
manipulated, in addition to violations there is also a waste of paper and
\end{tabular}
\end{abstract}

Infotech: Jurnal Informatika \& Teknologi is licensed under a Creative Commons AttributionNonCommercial 4.0 International License. p ISSN 2722-9378| e ISSN 2722-9386 


\begin{abstract}
requires a lot of space for storage. One of the actions to solve this problem is by building the Teacher Assistance application to manage android-based teacher activities with geofencing techniques, meaning that the system will detect if students are not in the classroom then unable to conduct attendance in the lesson. Furthermore Web Services was built to recapitulate the attendance data of the Student. By utilizing private or WiFi network connections, GPS and Map Applications students can make attendance at the lessons taken. After testing the teacher's assistance application can manage student attendance, the teacher can make a schedule, and monitor the condition of attendance per subject taken by students, then the system can recapitulate student attendance based on lessons learned. With this application students can enter learning without writing on the attendance paper but using their respective smartphones and to recapitulate student attendance using the website application to display attendance according to the lessons taken. Based on the results of testing this application runs well on Android applications version 7 and above, with this application it is expected to help teachers manage classroom learning.
\end{abstract}

\section{PENDAHULUAN}

Sekolah XYZ adalah sebuah sekolah yang berasaskan nilai-nilai keislaman yang berlokasi di wilayah Bogor Timur yang berdiri sejak Tahun 2004 yang merupakan sebuah sekolah tingkat atas pada bidang kejuruan.

Sistem pencatatan kehadiran siswa masih dilakukan secara manual menggunakan form kehadiran di kelas masing-masing ketika siswa masuk. Proses kehadiran yang masih manual tersebut menemukan beberapa kendala selain memungkinkan adanya kecurangan juga siswa harus mencatat bergiliran dalam mencatat, hal ini menjadi kecemburuan siswa yang lainya yang sering rajin belajar.

Selain masalah diatas juga tentunya dengan banyaknya penggunaan kertas dalam proses pencatatan kehadiran maka akan menjadikan pemborosan pada kertas dan file penyimpanan pada file kehadiran tersebut dan dengan sistem file pada kertas ini bermasalah dalam hal penyimpanan karena file kertas ini masa simpannya hanya bertahan paling lama 1 tahun padahal data kehadiran ini akan berguna di kemudian hari.

Rekapitulasi data kehadiran oleh bagian akademik pada setiap siswa setiap bulannya akan memerlukan waktu yang lama dalam proses perhitungan setiap kehadirannya karena harus input data satu-satu setiap siswa. Dengan pengolahan data seperti itu kurang efektif karena memerlukan waktu yang lama dan keakuratan input data yang masih kadang-kadang terjadi salah input.

Aplikasi Asistensi Guru salah satunya bisa mengatur kehadiran siswa sistem ini nantinya dibangun memanfaatkan teknologi telepon pintar Android dengan menggunakan fasilitas Internet WiFi dan GPS sebagai media dalam melakukan kehadiran untuk seluruh siswa. Ketika akan melakukan kehadiran siswa harus terdaftar di sistem dan setelah terdaftar maka siswa di Sekolah XYZ akan melakukan login selanjutnya memilih fitur kehadiran di area siswa, tombol fitur untuk kehadiran ini akan aktif jika 
siswa berada pada area geofence [1], atau pagar yang ditentukan sebagai batas lokasi lintang dan bujur wilayah Sekolah, siswa dapat melakukan kehadiran belajar dengan pemanfaatan GPS dari telepon pintar masing-masing. Dari penelitian sebelumnya tentang proses kehadiran siswa penulis melihat masih sedikit terkait penelitian yang mengkombinasikan dari pemanfaatan letak lokasi dan sistem asistensi guru di kelas dalam mengelola sistem kehadiran pada pembelajaran siswa. Dengan dikembangkannya aplikasi ini berharap bisa menjadi solusi dalam pengelolaan sistem kehadiran yang mengharuskan siswa berada di ruang kelas.

\section{METODE}

Penelitian ini dilakukan di sebuah sekolah di wilayah bogor timur, dimana analisis dan desain perancangan menggunakan metode UML [2] dan untuk pengembangan aplikasi menggunakan metode WaterFall [3], adapun langkah-langkah penelitian ini dilakukan beberapa tahapan diantaranya preparation, literature study, system design \& development, testing \& evaluation dan deployment seperti terlihat pada gambar 1.



Implement Application Using Java Language and Android

Gambar 1. Tahapan penelitian

\subsection{Aplikasi Asistensi Guru.}

Aplikasi asistensi guru adalah aplikasi yang membantu guru dalam mengelola pembelajaran secara jarak jauh atau dengan tatap muka di kelas, tetapi dalam kasus ini siswa harus hadir di kelas atau lokasinya tidak jarak jauh.

\subsection{Sistem Operasi Android.}

Arsitektur sistem operasi perangkat untuk bergerak dengan android pertama kali dikembangkan oleh Android Inc. Sekarang dimiliki oleh Google dan merilis AOSP (Android Open Source Project) pada tahun 2007. Sekarang dibawah pengawasan OHA (Open Handset Alliance). Perangkat lunak yang digunakan di dalamnya diluncurkan di bawah lisensi Apache sebagai sumber terbuka (open source). Open Handset Alliance adalah kumpulan dari banyak perusahaan pembuat hardware dan software untuk alat telekomunikasi yang mungkin juga meliputi perusahaan ternama seperti Motorola, HTC, 
NVIDIA, Qualcomm, Google dan T Mobile, di mana Android adalah OS yang dapat beradaptasi. Tujuan intinya adalah untuk membangun peralatan canggih sesuai dengan teknologinya yang mungkin jauh lebih sedikit waktu dan biaya dan juga meningkatkan layanan dan menyediakan fitur terbaik untuk pelanggan [4].

Sistem Operasi android adalah sistem operasi yang berbasis open source dari inti kernel versi Sistem Android termasuk sistem operasi yang dirancang untuk digunakan pada perangkat mobile karena perangkat ini lebih flexible. Pada perkembangannya selama ini sistem operasi ini sudah banyak digunakan pada berbagai perangkat Audio/Video misalnya Komputer, TV Kabel dan mobile stereo [5]

\subsection{Geofencing}

Teknik Geofence atau Geofencing adalah teknik dalam mendeklarasikan sebuah area pagar pada peta Geo (peta bumi) memungkinkan untuk menyediakan context-based action secara lebih fleksibel [6]. Geofencing adalah penghalang virtual yang digunakan sistem penentuan posisi global (GPS) atau identifikasi frekuensi radio (RFID) untuk menentukan batasan geografis. Fungsinya memungkinkan aplikasi untuk memicu ketika perangkat melintasi Geo-pagar dan memasuki (atau keluar) batas yang ditentukan. Notifikasi yang dikirim dapat berupa email atau SMS. Sebagian besar aplikasi Pagar Geo bergabung dengan Google Earth yang memungkinkan kita untuk menentukan batas di atas tampilan satelit dari area geografis tertentu. Beberapa aplikasi mendefinisikan batas oleh garis bujur dan garis lintang atau melalui peta yang dibuat pengguna dan berbasis web [7].

\subsection{Geofence Area}

Teknik ini menyediakan monitoring otomatis dari objek mobile yang bergerak di sekitar ataupun berada dalam area geofence. Peringatan akan berbunyi ketika perangkat mobile memasuki ataupun keluar dari batas (boundary) yang telah ditentukan. Dalam penetapan area geofence membutuhkan beberapa titik koordinat. Perhitungan algoritma itu akan dilakukan berdasarkan koordinat yang dihitung hal ini yang menjadi trigger untuk membuat peringatan, baik bersifat pribadi atau bebas dari geofence [6].

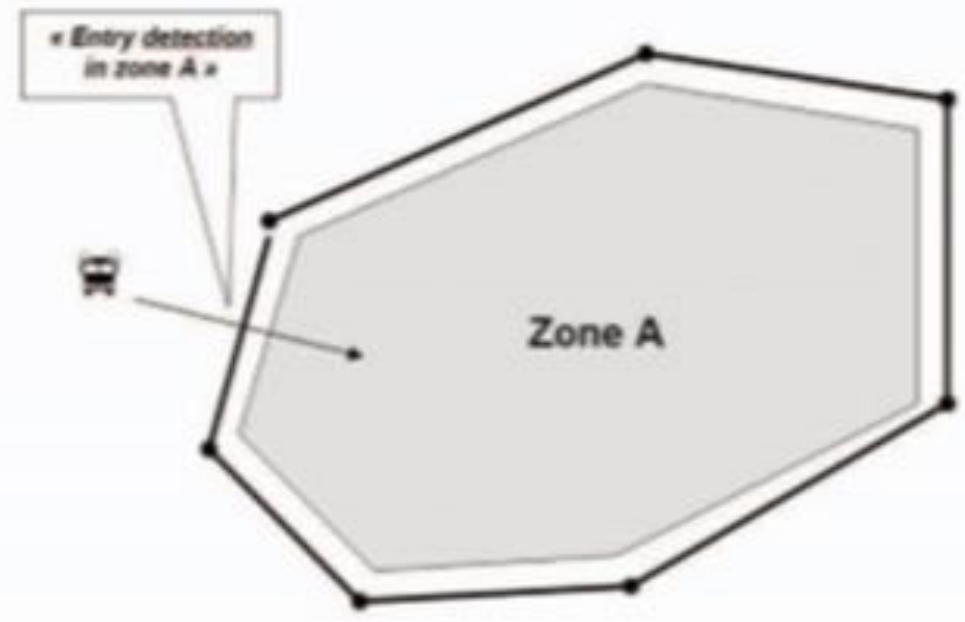


Gambar 2. Kondisi Geofence aktif (lingkaran hitam) berada di area A [8]

\subsection{API Google Map}

Sebuah Interface dari Google yang merupakan program interface yang diberikan oleh layanan Google agar aplikasi Google Maps bisa terhubung dengan Aplikasi Web atau Mobile. Untuk menampilkan Google Maps di web diperlukan javascript agar bisa menampilkan sebuah halaman web. API key dari mulai diperkenalkan sudah banyak mengalami perubahan sesuai dengan kebutuhan dan fleksibilitas pengontrolan Google Maps API Key, sekarang ini cara mendapatkan API Key syaratnya adalah harus mempunyai account di google dan email Gmail, setelah mempunyai account dan alamat Gmail akan digunakan untuk membuat API Key dengan mendapatkannya di link website https://code.google.com/apis/console/[9].

\subsection{Perangkat GPS}

Sebuah perangkat atau alat untuk menandai posisi letak bujur dan lintang di permukaan bumi yang membantu mensinkronkan letak posisi alat (GPS) yang berasal dari sinyal satelit. Sistem ini sekurang-kurangnya menggunakan empat satelit dalam mengirim gelombang mikro ke bumi. Kemudian sinyal ini akan ditangkap oleh atau receiver yang ada di bumi yang berfungsi dalam mendeskripsikan posisi, arah, kecepatan kontrol waktu saat melakukan pengiriman data setelah dihasilkan sinkronisasi [10].

\subsection{Location Based Service}

Service Location terbaik merupakan jenis IP tanpa Kabel yang menggunakan informasi geografis untuk melayani tentang keberadaan letak lokasi dari penggunanya [11]. Jenis layanannya yaitu memberikan petunjuk tentang keberadaan posisi lokasi/perangkat smartphone berada. Location Based Service adalah bentuk pelayanan secara personal kepada setiap pengguna perangkat mobile sesuai dengan lokasi pengguna berada berdasarkan update dari penyimpanan GPS receiver dari satelit.

\subsection{Haversine}

Metode Haversine adalah salah satu metode untuk menghitung jarak antara dua titik dengan memperhitungkan bahwa bumi bukanlah sebuah bidang yang datar saja tetapi dengan memperhitungkan bahwa bumi memiliki derajat kelengkungan. Metode ini digunakan sebagai rumus untuk menghitung jarak antara kedua titik berdasarkan pada kedua panjang garis lurus antara kedua titik yang merupakan garis bujur dan garis lintang [12].

\section{$2.9 U M L$}

Metode Perancangan dengan UML adalah salah metode perancangan dalam pembuatan software dengan menggunakan teknik pemrograman berorientasi objek [2]. Adapun keuntungan perancangan dengan UML.

a. Mengimplementasikan bahasa pemodelan yang tidak terikat oleh bahasa pemrograman dan proses rekayasa perangkat lunak.

b. Mengintegrasikan praktek terbaik yang terdapat dalam pemodelan. 
c. Memberikan model yang siap digunakan, merupakan bahasa pemodelan dalam memvisualisasikan responsif untuk mengembangkan dan bisa switch model dengan flexible dan dimengerti secara umum.

Metode perancangan UML diciptakan oleh sebuah organisasi internasional yang merupakan developer atau pengembang software dan merupakan pengguna sistem komputer tersebut [13].

\section{HASIL DAN PEMBAHASAN}

\subsection{Analisis Sistem}

Dalam memulai proses belajar di sekolah XYZ adalah pada saat melakukan absen dengan cara siswa harus masuk ke dalam kelas setelah masuk maka siswa akan mengisi kehadiran dengan cara mengisi data form kehadiran secara manual. Dalam membuat laporan tentang kebutuhan data kehadiran siswa melalui beberapa tahapan.

\subsubsection{Tahap Pembuatan data Kehadiran}

Pada tahapan ini siswa sekolah XYZ mengisi form kehadiran pada pelajaran yang diambil sebanyak jumlah kehadiran dalam satu semester. Adapun tahap pembuatannya seperti gambar 3 .



Gambar 3. Tahapan proses kehadiran.

\subsubsection{Tahapan Rekap data Kehadiran.}

Pada tahapan ini bagian akademik sekolah XYZ akan meng-entri secara manual data kehadiran ke dalam aplikasi pengolahan dengan komputer untuk menentukan data kehadiran setiap siswa sejumlah kehadiran pada satu semester. Adapun tahapan rekap data seperti gambar 4. 


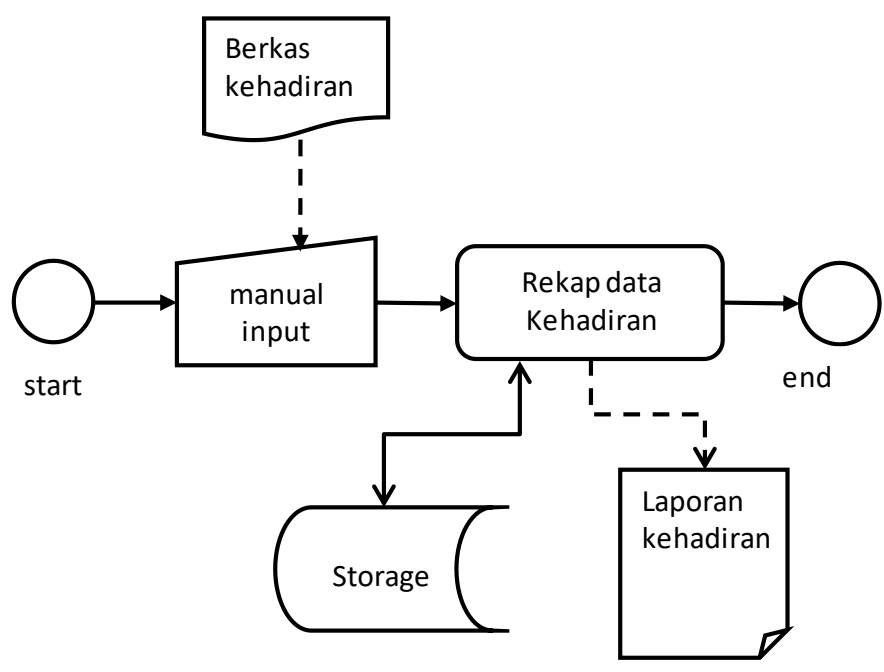

Gambar 4. Tahapan proses rekap data

\subsection{Arsitektur Aplikasi Asistensi Guru.}

Dalam perancangan aplikasi asistensi guru ini yang akan dibangun adalah dengan menyediakan antarmuka pada aplikasi berbasis mobile dan web, yang mana untuk yang berbasis mobile untuk digunakan oleh siswa dan guru dalam melakukan proses kehadiran dengan syarat proses kehadiran bisa terjadi hanya di area pagar geo atau area geofencing. di kelas dan guru akan memonitor kehadiran siswa membuat jadwal, membuat materi dan melihat profil siswa dan yang berbasis web akan digunakan oleh admin akademik dalam mengelola data kehadiran tersebut. Dengan pemanfaatan aplikasi GPS dan Internet maka aplikasi yang berbasis mobile ini akan mengirimkan data lokasi lintang dan bujur ke server dimana lokasi siswa berada sesuai lokasi minimum jarak untuk bisa melakukan kehadiran. Sedangkan untuk sistem aplikasi web adalah untuk melakukan pengolahan data kehadiran. Dan jika diperbandingkan dengan penelitian-penelitian sebelumnya aplikasi asistensi pengajaran itu belum secara spesifik dalam mengelaborasi antara sistem asistensi dengan penggunaan pagar geo. 
Iskandar ${ }^{*}$, Umar Tsani Abdurrahman²

Implementasi Aplikasi Asistensi Guru di Kelas dengan Teknik Geofencing Berbasis Android

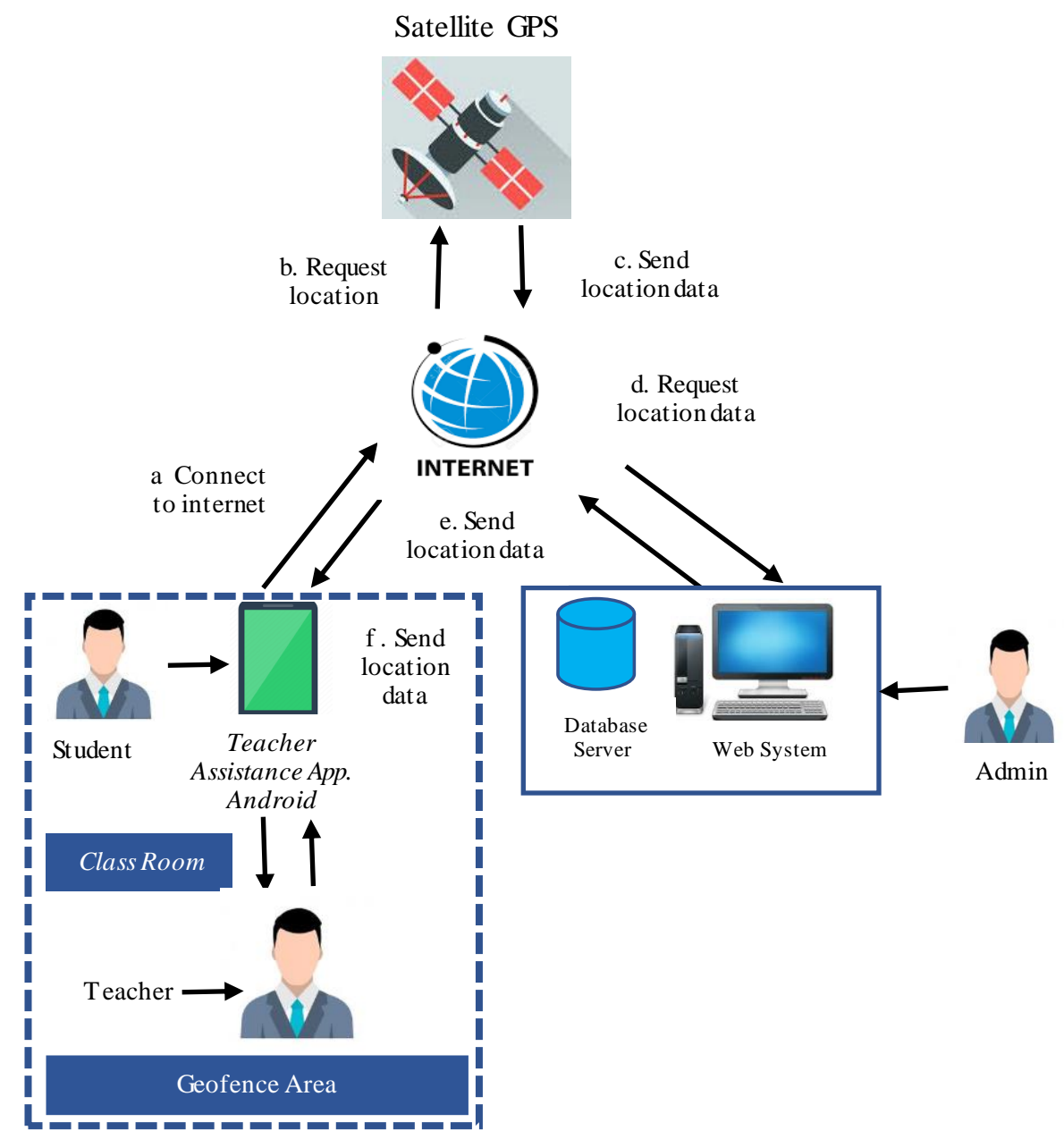

Gambar 5. Arsitektur sistem usulan.

\subsection{Pembuatan Use Case Diagram.}

Dalam perancangan sistem digunakan metode UML dan use case dalam perancangan pada aplikasi asistensi guru pada mobile android adalah seperti pada gambar 6 .

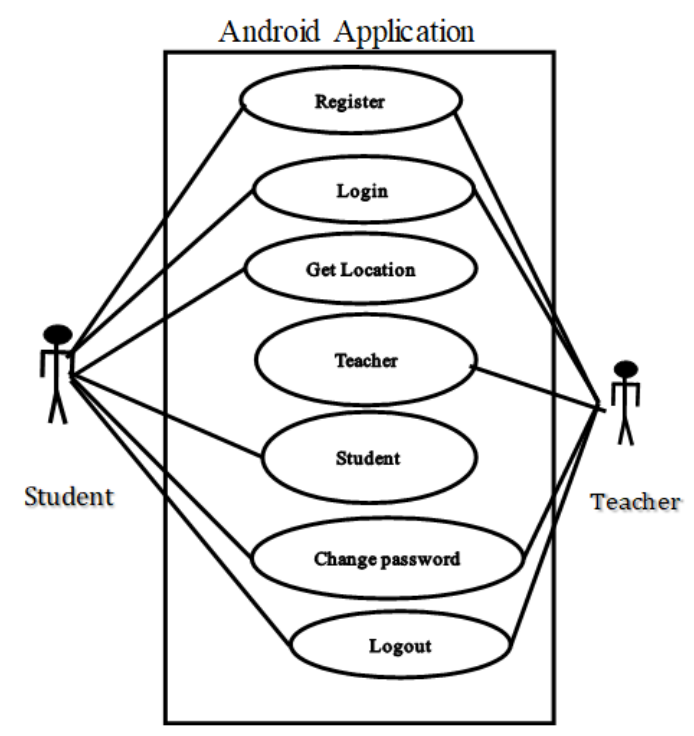

Gambar 6. Use case diagram aplikasi android 


\subsection{Perancangan Database}

Proses selanjutnya adalah perancangan database bertujuan untuk menggambarkan relasi antar tabel satu dengan tabel lainnya tabel siswa berelasi dengan tabel login, tabel login berelasi dengan tabel guru, attendance, pelajaran, untuk tabel guru berelasi dengan tabel jadwal dan pelajaran. Untuk rancangan relasi tabel seperti pada gambar 7.

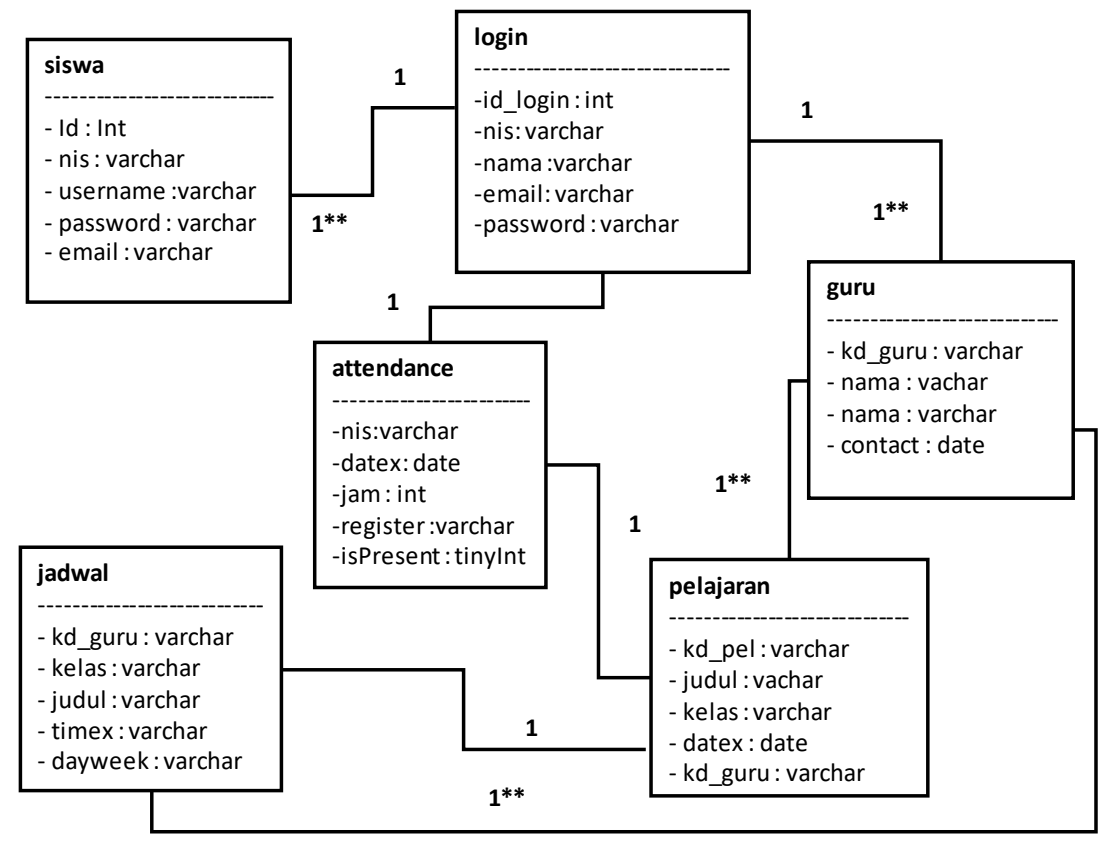

Gambar 7. Rancangan class diagram

\subsection{Analisis Kebutuhan Sistem}

Pada tahap analisis ini sistem Aplikasi Asistensi Guru bagaimana secara kebutuhan fungsional. Pada pengembangan layanan kehadiran siswa pada Aplikasi Asistensi Guru berbasis geofencing ini memiliki fungsi kepada user (siswa), guru (User-admin) dan admin (akademik sekolah). Layanan yang dikembangkan ini harus mampu memenuhi kebutuhan fungsional, 1) Siswa akan mendaftarkan kehadiran di kelas menggunakan smartphone untuk bisa mengikuti pelajaran sebagai catatan kehadiran pada pelajaran yang ambil. 2) Setelah setelah terdaftar siswa bisa mengakses sistem aplikasi Asistensi Guru dengan cara login terlebih dahulu, siswa tidak akan bisa melakukan proses kehadiran jika tidak berada di radius bujur dan lintang letak posisi sekolah berada pada radius $10 \mathrm{~m}$ dimana kelas berada, karena tombol proses kehadiran di aplikasi akan disable (tidak tampak dilayar). 3) Setelah login sukses pada sistem siswa maka melakukan pengisian data pada smartphone untuk mengikuti pelajaran yang diambil sesuai jadwalnya dan melakukan penyimpanan data. 4) Guru akan melihat kehadiran siswa dalam pelajaran yang diikuti sesuai jadwal yang ditentukan oleh guru yang bersangkutan. 5) Akademik sekolah sebagai admin bisa melakukan rekapitulasi data kehadiran siswa sesuai jadwal pelajaran dan guru yang bersangkutan.

\subsection{Spesifikasi Perangkat Hardware dan Software.}

Pada tahapan perancangan aplikasi Asistensi Guru di Kelas menggunakan H/S dengan spesifikasi, perangkat keras, dan perangkat lunak. 
a. Perangkat Keras.

* Desktop.

- Processor Intel Core i3 $(2.1 \mathrm{GHz})$.

- RAM 4GB.

- HDD 1TB.

Mobile Android (emulator)

- Samsung Galaxy J7 Core $(2.1 \mathrm{GHz})$.

- RAM 2 GB.

- HDD 16 GB.

b. Perangkat Lunak.

- Sistem OS: Windows 8.164 bit.

- Bahasa Program: Java-Android, PHP dan Jason

- Databases : SQLite dan MySQL

- Editor : Android Studio dan Notepad ++

- Server Localhost: Apache XAMPP

- API Level Java : JDK 1.7

\subsection{Black Box Testing}

Dalam melakukan testing pada aplikasi asistensi guru ini menggunakan spesifikasi perangkat mobile pada tabel 1 .

Tabel 1. Perangkat uji coba

\begin{tabular}{cccc}
\hline No. & Nama Smartphone & Android Versi & Hasil \\
\hline 1. & Samsung Galaxy J7 Core & Versi 7.0 & Running \\
2. & OPPO3s & Versi 8.1 & Running \\
\hline
\end{tabular}

Adapun hasil dari pengujian sistem dengan metode Black box testing yang dijelaskan pada tabel 2 .

Tabel 2. Black Box Testing

\begin{tabular}{|c|c|c|c|}
\hline No & $\begin{array}{l}\text { Skenario } \\
\text { Pengujian }\end{array}$ & Hasil Yang diharapkan & Kesimpulan \\
\hline 1. & $\begin{array}{l}\text { Login } \quad \text { user } \\
\text { (Siswa) }\end{array}$ & Berhasil login sesuai email dan password & Valid \\
\hline 2. & $\begin{array}{l}\text { Siswa bisa Join } \\
\text { Class }\end{array}$ & $\begin{array}{l}\text { Jika jarak siswa di lokasi/class Geofencing }<10 \\
\text { m }\end{array}$ & Valid \\
\hline 3. & Siswa masuk ke & Siswa bisa melakukan proses kehadiran & Valid \\
\hline 4. & halaman Area & Siswa bisa melakukan registrasi belajar & Valid \\
\hline 5 , & Siswa & Siswa bisa melakukan update data diri & Valid \\
\hline 6. & $\begin{array}{l}\text { Login } \\
\text { (Guru) }\end{array}$ & Berhasil login sesuai email dan password & Valid \\
\hline 7. & & Guru bisa membuat Jadwal Pelajaran & Valid \\
\hline
\end{tabular}


8. Guru masuk ke Guru bisa membuat Materi Ajar Valid

9. halaman Area Guru bisa melihat Data kehadiran siswa Valid

Dari pengujian pada perangkat tersebut diatas aplikasi asistensi guru dengan geofencing dapat berjalan dengan baik pada versi android 7.0 keatas.

\subsection{Tampilan Aplikasi Asistensi Guru}

Dibawah ini adalah tampilan dari aplikasi asistensi guru diantaranya seperti terlihat pada menu drawer dibawah ini, yaitu menu Home, About, Guru, Cari Lokasi, Siswa, Ganti password dan Keluar, seperti pada gambar 8, gambar 9, gambar 10, gambar 11 dan gambar 12 .

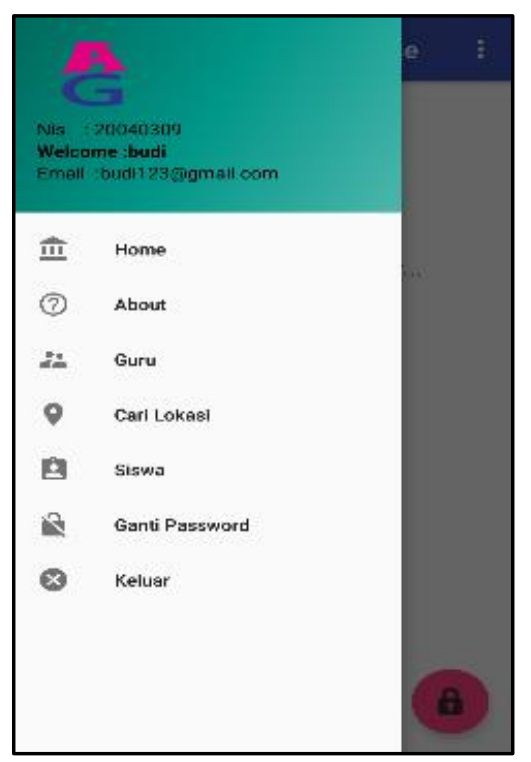

Gambar 8. Menu drawer aplikasi asistensi guru

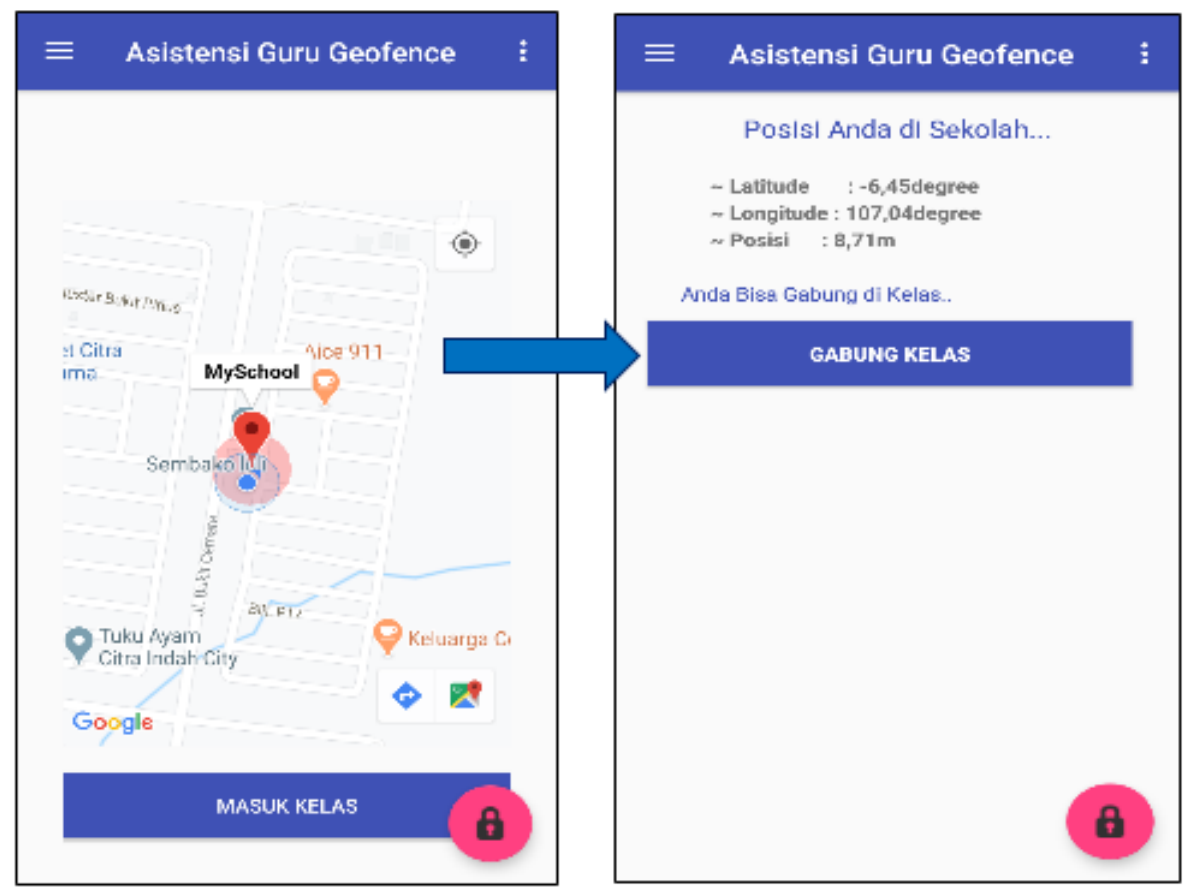

Gambar 9. Siswa harus berada di area geofencing absen kehadiran 
Iskandar $^{1 *}$, Umar Tsani Abdurrahman ${ }^{2}$

Implementasi Aplikasi Asistensi Guru di Kelas dengan Teknik Geofencing Berbasis Android

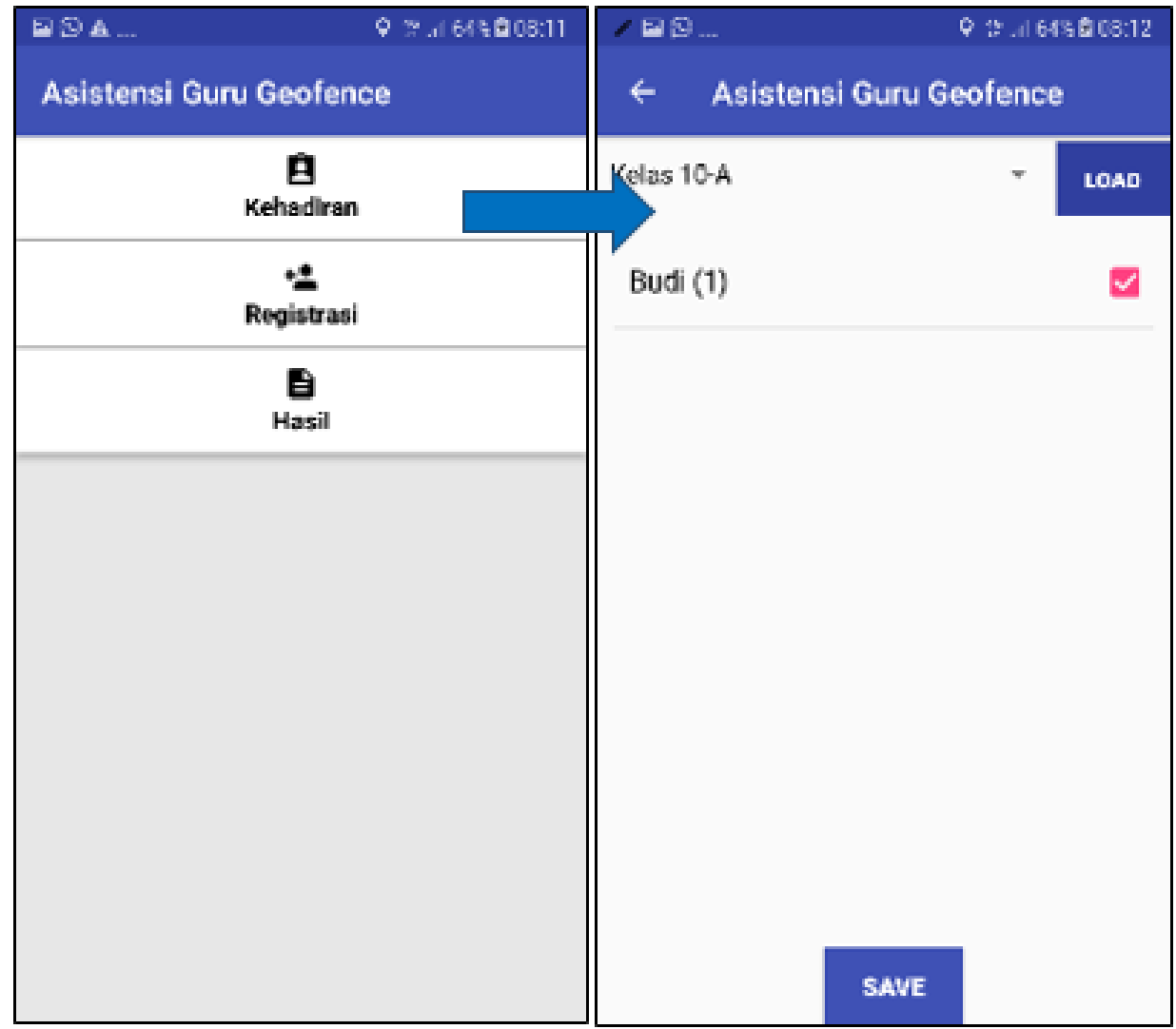

Gambar 10. Siswa entri data kehadiran

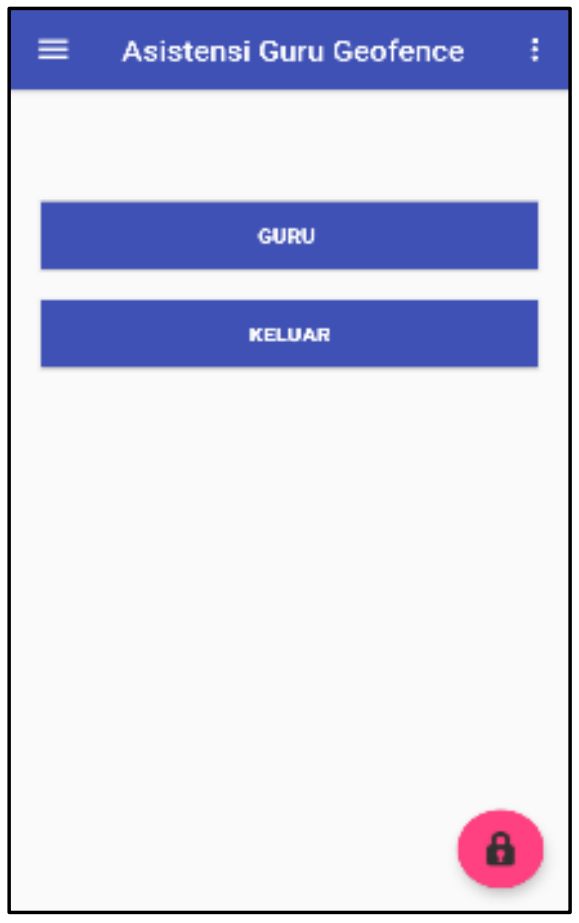

Gambar 11. Halaman guru 


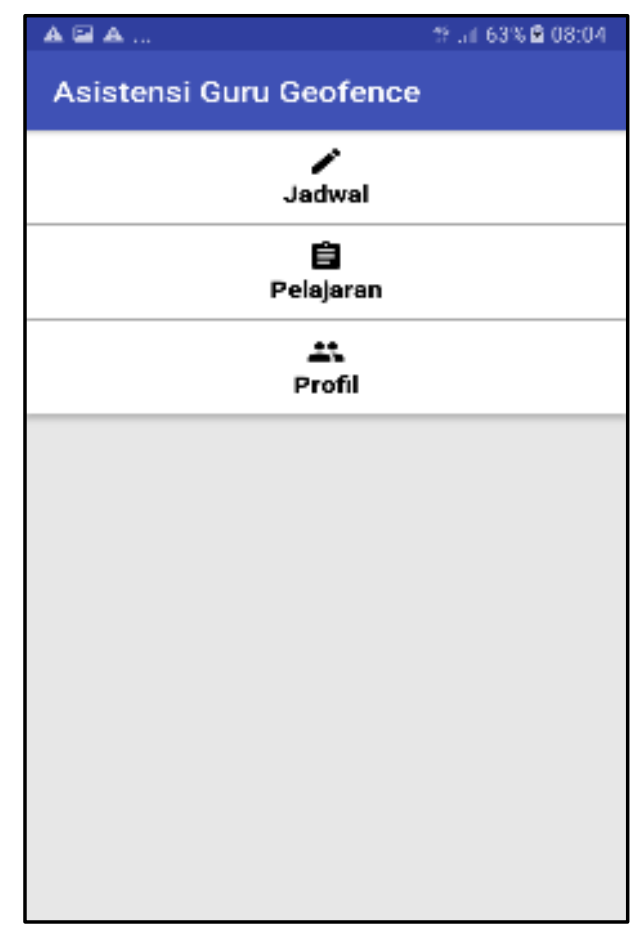

Gambar 12. Halaman activity guru

\section{SIMPULAN}

Adapun kesimpulan dari hasil penelitian implementasi Aplikasi Asistensi Guru di kelas menggunakan teknik geofencing dalam monitoring kehadiran siswa menghasilkan performa yang baik pada versi android 7.0 ke atas setelah hasil uji pada perangkat bergerak pada spesifikasi seperti diatas dengan catatan layanan aplikasi ini membutuhkan perangkat GPS di perangkat bergerak siswa dan internet yang cukup.

\section{DAFTAR PUSTAKA}

[1] Beny, J. Budiman, and Agus Nugroho, "Implementasi Geofencing Pada Aplikasi Layanan Pemantau Anak Berbasis Lokasi," Semin. Nas. IPTEK Terap. 2017, no. ISSN: 2579-9045, 2017.

[2] E. F. Wati and A. A. Kusumo, "Penerapan Metode Unified Modeling Language ( UML ) Berbasis Desktop Pada Sistem Pengolahan Kas Kecil Studi Kasus Pada PT Indo Mada Yasa Tangerang," vol. 5, no. 1, pp. 24-36, 2016.

[3] S. T. ind, Karambir, "A Simulation Model for the Spiral Software Development Life Cycle," Int. J. Innov. Res. Comput. Commun. Eng., vol. 03, no. 05, pp. 3823-3830, 2015.

[4] M. Haris, "Evolution of Android Operating System : A Review," no. November 2017, 2018.

[5] Susanto and S. Hermawan, Mudah Membuat Aplikasi Android. Yogyakarta: Andi offset, 2011.

[6] Beny, J. Budiman, and A. Nugroho, "Implementasi Geofencing Pada Aplikasi Layanan Pemantau Anak Berbasis Lokasi," Tek. Inform., pp. 15-17, 2017.

[7] M. Makhtar, R. Rosly, S. A. Fadzli, S. N. W. Shamsuddin, and A. A. Jamal, "Implementation of mobile attendance application using geo-fence technique," ARPN J. Eng. Appl. Sci., vol. 11, no. 5, pp. 3391-3395, 2016.

[8] F. Reclus and K. Drouard, “Geofencing for fleet \& freight management," 2009 9th Int. 
Conf. Intell. Transp. Syst. Telecommun. ITST 2009, pp. 353-356, 2009.

[9] A. R. Ruchendar, G. T. Mardiani, J. Dipatiukur, N. Bandung, and J. Barat, "PEMBANGUNGAN APLIKASI ABSENSI MEMANFAATKAN WIFI DENGAN MENGGUNAKAN GPS BERBASIS ANDROID DI PT . DINUS CIPTA MANDIRI."

[10] D. H. Gintoro, Iwan Wijaya Suharto, Febiyan Rachman, "Analisis Dan Perancangan Sistem Pencarian Taksi Terdekat Dengan Pelanggan Menggunakan Layanan Berbasis Lokasi," vol. 2010, no. Snati, 2010.

[11] Ardiansyah, Mengenal Location Based Service (LBS). Yogyakarta: Andi offset, 2011.

[12] R. Herwan, D. Putra, H. Sujiani, and N. Safriadi, "Penerapan Metode Haversine Formula Pada Sistem Informasi Geografis Pengukuran Luas Tanah,” vol. 1, no. 1, 2016.

[13] R. M. Akbar and N. Prabowo, "Aplikasi Absensi Menggunakan Metode Lock GPS Dengan Android di PT.PLN (Persero)," Majapahit Techno, 2015. 